\title{
Evaluation of the Effects of Irradiation of Peanut Grain by a Gamma-Ray Beam on Culture
}

\author{
G. Mbaye', M. Soumboundou', L. A. D. Diouf', B. Ndong², A. R. Djiboune, P. M. Sy'1, S. M. Dieng1, \\ M. Diouf ${ }^{1}$, N. N. Diouf ${ }^{1}$, A. Barry' ${ }^{1}$ M. Diarra1 ${ }^{1}$ \\ ${ }^{1}$ Laboratory of Physics and Pharmaceutical Biophysics, Faculty of Medicine, Pharmacy and Odontology, UCAD, Dakar, Senegal \\ ${ }^{2}$ Laboratory of Medical Biophysics and Nuclear Medicine, Faculty of Medicine, Pharmacy and Odontology, UCAD, Dakar, Senegal \\ Email: mbaygo@yahoo.fr, bayosoumboundou@hotmail.com, mounbeni@yahoo.fr
}

How to cite this paper: Mbaye, G., Soumboundou, M., Diouf, L.A.D., Ndong, B., Djiboune, A.R., Sy, P.M., Dieng, S.M., Diouf, M., Diouf, N.N., Barry, A. and Diarra, M. (2017) Evaluation of the Effects of Irradiation of Peanut Grain by a GammaRay Beam on Culture. Open Journal of Biophysics, 7, 94-100.

https://doi.org/10.4236/ojbiphy.2017.73008

Received: May 15, 2017

Accepted: July 1, 2017

Published: July 4, 2017

Copyright (c) 2017 by authors and Scientific Research Publishing Inc. This work is licensed under the Creative Commons Attribution International License (CC BY 4.0).

http://creativecommons.org/licenses/by/4.0/

\begin{abstract}
The problems of agriculture in Senegal result in a low yield per hectare and poor seed quality contributing strongly to the decline in productivity. Mutagenesis by X- or Y-ray irradiation makes it possible to obtain genetic mutants necessary to improve production. It is in this context that we undertook this study to evaluate the effects induced on the cultivation of peanut seeds irradiated by X-rays at low doses applied in radiotherapy. X-ray irradiation of four $(2,3,4,5)$ lots of peanuts are performed with respectively $0.5,1.5,2$ and 4 Gray using the cobalt 60 therapy device (Alcyon II). The seeding of the seeds and then the following-up of the crops during 35 days allowed us to study the parameters of germination, growth and yield. The results obtained after monitoring revealed that the irradiation did not have any significant impact on germination and would appear to temporarily inhibit the growth rate compared to the control batch. However, the decrease in weight of the harvested seeds can be explained by the absence of fertilizer during the cultivation.
\end{abstract}

\section{Keywords \\ Peanuts, Culture, Irradiation, X-Rays}

\section{Introduction}

Since the 1970s, Senegalese agriculture, which is mainly based on groundnut as the main cash crop, has been in a deep crisis that has not ceased to have repercussions on the national economy. Despite groundnut production that rose from 731,209 tonnes in 2009 to 1,032,631 tonnes in 2010 (41.2\% increase in relative value), production potential is far from being achieved [1]. The problems affecting agriculture, in Africa in general and Senegal in particular, result in a low yield per hectare, most often linked to seed capital with a structural deficit. 
Poor seed quality contributes significantly to declining productivity. Hence, the search for new varieties for cultivation and human consumption has become a priority. Previously, it was essentially a choice between good and bad plants [2].

Improved agricultural production can be achieved in various ways. One of these lies in the search for species or varieties which, having regard to their usable characteristics, have inherited possibilities superior to those of species or varieties already existing. Another way is to use the different techniques of experimental production of hereditary variations by the use of chemical mutagens or ionizing radiations such as $\mathrm{X}$-rays. These agents induce, within the living organisms subjected to their action, hereditary variations generally identical to those occurring in nature but with a frequency 10 to 100 times greater [2].

The possibility of producing hereditary variations therefore constitutes a fact of great importance for obtaining genetic mutants necessary to improve the production of the crop plants and adapt them to conditions of cultivation which do not always play in their favor.

Mutagenesis is now widely used for vegetatively propagated ornamental plants but also for cereals and other field crops [3]. X rays irradiation on plants for mutation has received much attention in recent years due to changes in plant cell structure and metabolism, e.g. dilation of thylakoid membranes alteration of photosynthesis, modulation of the antioxidant system, and accumulation of phenolic compounds. X-rays belong to ionizing radiation and interact with the atoms or molecules of the medium to produce free radicals in the cells. These radicals can damage or modify important plant cell components, morphology, anatomy, biochemistry and plant physiology depending on the doses of irradiation [4]. It has been generally accepted that reactive oxygen species (ROS) such as hydrogen peroxide $\left(\mathrm{H}_{2} \mathrm{O}_{2}\right)$, superoxide anion $\left(\mathrm{O}_{2}^{-}\right)$, Hydroxyl $(\mathrm{HO})$ radicals are produced by the radiolysis of water. Among these ROS, $\mathrm{H}_{2} \mathrm{O}_{2}$ is a normal metabolite in cells under optimum plant growth conditions and is not particularly cytotoxic, but when its concentrations are increased by environmental stresses and ionizing radiation, it can lead to cell lethality [5]. To cope with the damage caused by the ROS, the cells possess a complete and integrated endogenous enzymatic defense system. Indeed, Peroxidase (POD), superoxide dismutase (SOD) and catalase (CAT) represent the endogenous enzymatic defense of the plant cell that becomes active during the cellular lesion. In fact, it has been reported that the activities of these sweeping enzymes are generally increased in various plant species after treatment with ionizing radiation [6]. In a wide range physiological modifications have been described by many researchers in plants exposed to $\mathrm{X}$-rays. The commonly observed abnormalities are improvement or inhibition of germination, growth of seedlings and other biological responses [7]. It is in this context that we undertook this study in order to evaluate immediate effects of low and moderate X-rays on peanut plant growth and changes in the development of irradiated seeds. In order to answer these questions, we analyzed the 
quantitative characteristics related to growth and reproduction.

\section{Materials and Methods}

We used peanut seeds (Arachis hypogaea) (Fabaceae), a variety 55 - 437, supplied by the Senegalese Institute of Agricultural Research (I.S.R.A.) The seeds were irradiated with a ${ }^{60} \mathrm{Co} x$-ray source (ALCYON II), a cobaltotherapy radiotherapy device used in the Cancer and Radiotherapy Institute of the Aristide Le Dantec Hospital. The seeds were sorted manually and stored in plastic bags. The seeds were selected manually and then stored in plastic bags and divided into five (5) batches of $60 \mathrm{~g}$. The 4 batches are irradiated using a ${ }^{60} \mathrm{Co} \mathrm{X}$-ray emitting source (Alcyon II, dose rate at $5 \mathrm{~cm} 1139 \mathrm{~Gy} / \mathrm{min}$ ) at doses of 0.5, 1.5, 2, 4 Gy. Exposure time at the seed level was calculated using conventional computerized radiotherapy treatment planning software. The seeds to be irradiated are suitably placed on a stainless steel tray so that they are not superimposed; to have the same homogeneous processing surface and penetration depth for each seed. The seeds are stored in plastic bags, protected from moisture, until sowing. Then they were sown without adding fertilizers to the botanical garden of the faculty of medicine, pharmacy and odontology of Cheikh Anta Diop University. Daily monitoring was carried out for 35 days to evaluate the various parameters (germination data, seedling growth) and yield. After harvesting, we measured the average weights of 100 pods and 100 seeds for each batch.

\section{Results}

Table 1 below shows the germination data of the different batches for ten (10) days after sowing.

In Figure 1, we represented the average growth rates (in $\mathrm{cm} /$ day) of the seedlings of the different batches during the 35 days of monitoring.

In Table 2 we reported the average weights of 100 pods and 100 seeds for each batch.

\section{Discussion}

$\mathrm{x}$-rays and $\gamma$-rays are the main ionizing radiation (IR) used in research to obtain improved genetic traits and to improve crop production [8] [9]. These ionizing

Table 1. Germination data.

\begin{tabular}{cccccc}
\hline & Batch 1 & Batch 2 & Batch 3 & Batch 4 & Batch 5 \\
\hline Number lifted & 12 & 7 & 6 & 13 & 10 \\
\% MG & 88 & 86 & 76 & 82 & 70 \\
T \% MG (days) & 3 & 4 & 3 & 3 & 3 \\
Nombre de morts & 8 & 9 & 12 & 10 & 16 \\
\hline
\end{tabular}

Number lifted: number of emergence on the first day of germination. \% MG: Maximum percentage of germination. T\% MG: Time to reach the maximum percentage of germination. Dead number: number of seedlings germinated and which did not survive. 


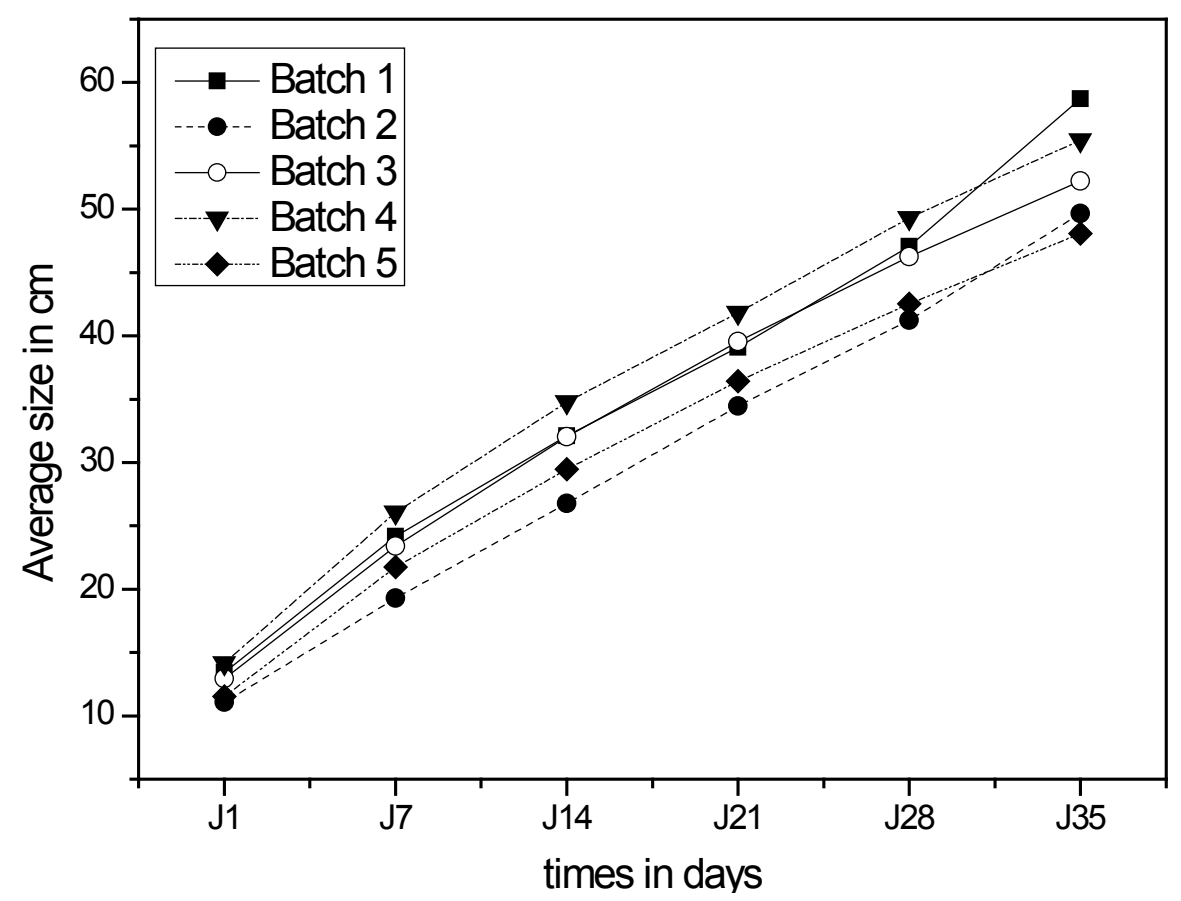

Figure 1. Shows average growth rates of seedlings ( $\mathrm{cm} /$ day).

Table 2. Average weight 100 pods (in g) and 100 seeds (in g).

\begin{tabular}{ccccccc}
\hline & Seeds & Batch 1 & Batch 2 & Batch 3 & Batch 4 & Batch 5 \\
\hline Weight of 100 pods (g) & 90 & 58.8829 & 61.0823 & 63.8760 & 60.6947 & 43.6772 \\
Weight of 100 seeds (g) & 37 & 24.9556 & 23.6896 & 30.8572 & 28.2531 & 23.4831 \\
\hline
\end{tabular}

radiations induce morphological, physiological and biochemical genetic changes, which vary with plant species, irradiation dose and type of radiation [10]. When IR doses are high, adverse effects on the morphology, physiology and biochemistry of plants can be explored [5].

ARENA C. et al. Confirm that higher doses of X-rays, 50 and $100 \mathrm{~Gy}$, strongly inhibit plant growth not only by reducing stem elongation, but also by preventing the budding of new leaves when compared with Low doses, i.e. 0.3 to 10 Gy of X-rays not influencing plant growth [11]. This notion was found in our study where all batches irradiated at doses below 10 Gy showed no morphological changes compared to the control group. However, it can not be excluded that these doses, apparently harmless to the first generation of plants (F1), could affect the second generation of the plant (F2). The survival of plants after irradiation is related to the extent of chromosomal damage. A high frequency of chromosomal lesions may be responsible for a reduction in plant growth and survival [12]. Thus, previous studies with gamma rays have shown that inhibition of growth is attributed to cell cycle inhibition and/or various genome damage [13].

In our experiment, the acceptable survival rates of all batches irradiated at low doses of X-rays predicted a good survival capacity of this species related to an effective repair system of radiation-induced lesions. 
This radioresistance can also be explained by two phenomena intrinsic to the seed. On the one hand, the linoleic acid content of fatty acids in the seed, which according to BOWEN and THIUK [14] is one of the possible factors responsible for the differences in radiosensitivity between certain species and, on the other hand, the rate of hydration of the Seeds during germination, which would be a trait of which GELIN et al. [15] Assumed that it could also play a role in the degree of seed radiosensitivity [16].

BILQUEZ A.F. et al. Showed for two varieties of seeds of composition in different levels of linoleic acid: 28.204 with $29 \%$ and 48.115 with $11 \%$; That the most X-ray-sensitive variety is the one with the highest level of linoleic acid [17]. This can be the case for our variety which has an average rate of $27.5 \%$ linoleic acid.

Our seedlings were carried out during the period of heavy rains (mid-August) allowing a rapid hydration of the seeds. However, according to the hypothesis issued by GELIN et al. [15] to explain some differences in susceptibility observed in peas, that the most sensitive variety is the one that hydrates most rapidly during germination.

The natural concentration of nitrate in soils is not high enough to ensure adequate crop yields. Crop yield depends, among other things, on the quality of nitrate available in the soil [18]. When nitrogen fertilization is non-limiting, organic fertilizers have contrasting effects on crop yields; Providing sufficient nitrogen to the plant early in growth can sometimes solve the problems of phosphorus availability, thus increasing plant vigor and growth, and consequently its root capacity to explore a greater volume of soil and also A better seed yield [19] [20].

The low weight of the seeds and the low yield of our crops could be explained by the lack of fertilizer use.

\section{Conclusion}

The results obtained show a slower growth rate for the control batch than for the other batches and a maximum germination time of 3 days. That said, the harvested seed weights are lower than those seeded (90 g per 100 pods versus 37 g per 100 seeds). Although authors have shown stimulating effects of gamma rays on the vegetative and reproductive traits of plants, our results did not show significant changes induced by short-term X-ray irradiation of peanut seeds. In sum, these low doses used, apparently harmless for the first generation of plants (F1) explaining the absence of morphological changes, could affect the second generation of the plant (F2). In perspective, the use of higher doses may be considered in previous studies correlated with biomolecular analyses.

\section{References}

[1] Ntare, B.R., Diallo, A.T., Ndjeunga, J. and Waliyar F. (2008) Groundnut Seed Production Manual. International Crops Research Institute for the Semi-Arid Tropics, 
$20 \mathrm{p}$.

[2] Novak, F.J. and Brunner, H. (1992) Selection of Plants: Induced Mutations for Better Crops. IAEA Bulletin, 4, 25-33.

[3] Bouharmont, J. (1994) Utilisation des mutations induites par la culture in vitro chez les plantes cultivées. Bulletin des Séances, Nouvelle Série, 40, 523-529.

[4] Seung, G.W., Byung, Y.C., Jae-Sung, K. and Jin-Hong, K. (2007) Effects of Gamma Irradiation on Morphological Changes and Biological Responses in Plants. Micron, 38, 553-564. https://doi.org/10.1016/j.micron.2006.11.002

[5] Kovacs, E. and Keresztes, A. (2002) Effect of Gamma and UV-B/C Radiation on Plant Cell. Micron, 33, 199-210. https://doi.org/10.1016/S0968-4328(01)00012-9

[6] Zaka, R., Vandecasteele, C.M. and Misset, M.T. (2002) Effects of Low Chronic Doses of Ionizing Radiation on Antioxidant Enzymes and G6PDH Activities in Stipacapillata (Poaceae). Journal of Experimental Botany, 53, 1979-1987. https://doi.org/10.1093/jxb/erf041

[7] Wi, S.G., Chung, B.Y., Kim, J.-H., Baek, M.-H., Yang, D.H., Lee, J.-W. and Kim, J.-S. (2005) Ultrastructural Changes of Cell Organelles in Arabidopsis Stem after Gamma Irradiation. Journal of Plant Biology, 48, 195-200. https://doi.org/10.1007/BF03030408

[8] Kim, J.H., Chung, B.Y., Kim, J.S. and Wi, S.G. (2005) Effects of in Planta GammaIrradiation on Growth, Photosynthesis and Antioxidative Capacity of Red Pepper (Capsicum annuum L.) Plants. Journal of Plant Biology, 48, 47-56. https://doi.org/10.1007/BF03030564

[9] Long, T.P. and Kersten, H. (1936) Stimulation of Growth of Soy Bean Seeds by Soft X-Rays. Plant Physiology, 11, 515-621. https://doi.org/10.1104/pp.11.3.615

[10] Demicco, V., Arena, C., Pignalosa, D. and Durante, M. (2011) Effects of Sparsely and Densely Ionizing Radiation on Plants. Radiation and Environmental Biophysics, 50, 1-19. https://doi.org/10.1007/s00411-010-0343-8

[11] Arena, C., Demicco, V., Aronne, G., Pugliese, M., et al. (2013) Response of Phaseolus vulgaris L. Plants to Low-Let Ionizing Radiation: Growth and Oxidative Stress. Acta Astronautica, 91, 107-114.

[12] Titov, V., Hohn, B. and Kovalchuk, I. (2000) Plants Experiencing Chronic Internal Exposure to Ionizing Radiation Exhibit Higher Frequency of Homologous Recombination than Acutely Irradiated Plants. Mutation Research, 449, 47-56.

[13] Preussa, S.B. and Britta, A.B. (2003) A DNA-Damage-Induced Cell Cycle Checkpoint in Arabidopsis. Genetics, 164, 323-334.

[14] Bowen, H.J.M. and Thiuk, J. (1961) Effects of seed Extracts on Radiosensitivity. Symposium on the Effects of Ionizing Radiation on Seeds IAEA, 75-82.

[15] Gelin, O., Ehrenberg, L. and Blixth, S.T. (1958) Genetically Conditioned Influences on Radiation Sensitivity in Peas. Agr. Hort. Genetica., 16, 78-102.

[16] Bilquez, A.F., Magne, C. and Martin, J.P. (1964) Bilan de six années de recherches sur l'emploi des rayonnements ionisants pour l'amélioration des plantes au Sénégal. Report of ORSTOM, Rome, Italy, 585-601.

[17] Bilquez, A.F. and Martin, J.P. (1961) Différence variétale de sensibilité aux rayons X chez l'Arachide. Journal d Agriculture Tropicale et de Botanique Appliquée, 8, 30 43.

[18] Gojon, A., Meyer, C., Morot-Godry, J.-F. and Quillere, I. (1997) Nitrates: De l'azote Minéral à la matière organique. Revue BIOFUTUR, 171, 28-32.

[19] Petit, J. and Jobin, P. (2005) La fertilisation organique des cultures. Fédération 
d'Agriculture Biologique du Québec, 48.

[20] Messiga, A.J., Jaidi, N., Morel, C., et al. (2012) Long Term Impact of Tillage Practices and Biennal P and N Fertilization on Maize and Soybean Yields and Soil P Status. Field Crops Reacherch, 133, 10-22.

Submit or recommend next manuscript to SCIRP and we will provide best service for you:

Accepting pre-submission inquiries through Email, Facebook, LinkedIn, Twitter, etc. A wide selection of journals (inclusive of 9 subjects, more than 200 journals) Providing 24-hour high-quality service User-friendly online submission system Fair and swift peer-review system Efficient typesetting and proofreading procedure Display of the result of downloads and visits, as well as the number of cited articles Maximum dissemination of your research work

Submit your manuscript at: http://papersubmission.scirp.org/ Or contact ojbiphy@scirp.org 